
LUDNOŚCI

\begin{abstract}
Streszczenie
Celem opracowania jest przedstawienie tendencji w obszarze współczesnych międzynarodowych ruchów ludności w okresie ostatniego ćwierćwiecza. Opracowanie składa się z czterech części. W pierwszej przeanalizowano zmiany wielkości i dynamikę migracji, w drugiej zbadano zmiany w zakresie kierunków imigracji, w trzeciej - emigracji, natomiast w czwartej omówiono przekazy migrantów. Wyniki badań wskazują, że skala migracji i jej znaczenie w gospodarce światowej wzrosły. Nastąpiły niewielkie zmiany w kierunkach migracji w taki sposób, że dominujący udział krajów rozwiniętych w wyborze krajów imigracji zwiększył się. Krajem z największą liczbą imigrantów nadal są USA, ale krajem, z którego wyemigrowało najwięcej ludzi stały się Indie, a w dalszej kolejności Meksyk i Rosja. Największe natężenie migracji występowało pomiędzy krajami rozwijającymi się. Nastąpił wzrost przekazów migrantów, głównie do uboższych krajów Południa.
\end{abstract}

Słowa kluczowe: migracje międzynarodowe, przekazy migrantów, emigracja, imigracja

\footnotetext{
* Adres e-mail: joanna.staskiewicz@gmail.com.
} 


\section{Wprowadzenie}

Jednym z przepływów międzynarodowych są międzynarodowe ruchy ludności. Stanowią one ważny element międzynarodowych stosunków gospodarczych. Przepływy ludzi między państwami ulegają nieustannym przeobrażeniem. Zmienia się skala, dynamika oraz struktura geograficzna migracji międzynarodowych. Przekształcenia zachodzą również w sferze przekazów migrantów. Celem artykułu jest przedstawienie tendencji w obszarze współczesnych międzynarodowych ruchów ludności w okresie ostatniego ćwierćwiecza (1990-2015).

\section{Wielkość migracji międzynarodowych}

W latach 1990-2015 migracje międzynarodowe cechował systematyczny wzrost. W 2015 roku liczba osób, która mieszkała poza granicami kraju swojego urodzenia wyniosła 243,7 miliona osób (por. tab. 1). Było to o $60 \%$ więcej w porównaniu z rokiem 1990. Tendencję rosnącą w znacznym stopniu można wyjaśnić zwiększającą się liczbą ludzi na świecie, bowiem jeśli porównać dynamikę wzrostu populacji na świecie z dynamiką wzrostu migrantów, okazuje się, że były one zbliżone. Ostatnią dekadę XX wieku charakteryzował jednak nieco szybszy wzrost populacji światowej niż migracji międzynarodowych, podczas gdy w XXI wieku tendencja ta odwróciła się i różnica w tempie wzrostu zwiększyła się (por. rys. 1). Wskazuje to na zwiększenie roli przepływu ludzi między krajami w gospodarce światowej.

Tabela 1. Wielkość migracji na świecie

\begin{tabular}{|c|c|c|c|c|}
\hline \multirow{2}{*}{ Rok } & Liczba migrantów & $\begin{array}{c}\text { Odsetek migrantów } \\
\text { w liczbie ludności }\end{array}$ & $\begin{array}{c}\text { Mediana wieku } \\
\text { migrantów }\end{array}$ & $\begin{array}{c}\text { Odsetek kobiet } \\
\text { wśród migrantów }\end{array}$ \\
\cline { 2 - 5 } & tys. & $\%$ & lata & $\%$ \\
\hline 1990 & 152563,2 & 2,9 &. & 49,1 \\
\hline 1995 & 160801,8 & 2,8 &. & 49,3 \\
\hline 2000 & 172703,3 & 2,8 & 38 & 49,4 \\
\hline 2005 & 191269,1 & 2,9 &. & 49,2 \\
\hline 2010 & 221714,2 & 3,2 &. & 49,0 \\
\hline 2015 & 243700,2 & 3,3 & 39 & 48,2 \\
\hline
\end{tabular}

Źródło: opracowanie własne na podstawie danych Organizacji Narodów Zjednoczonych (ONZ, 2015b, 2016). 
Rysunek 1. Dynamika ludności na świecie i międzynarodowych ruchów ludności w okresie 1990-2015

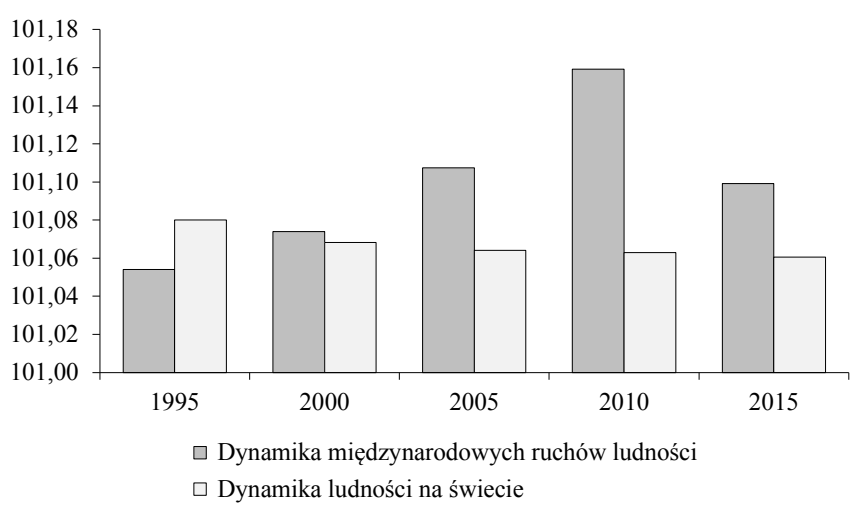

Źródło: obliczenia własne na podstawie danych Organizacji Narodów Zjednoczonych (ONZ, 2016).

W rezultacie w okresie 1990-2015 zanotowano wzrost udziału migrantów w liczbie ludności z 2,9\% do 3,3\% (por. tab. 1). Oznacza to, że w 2015 roku statystycznie co 30 mieszkaniec globu mieszkał poza krajem swojego pochodzenia.

Statystyczny portret migranta to osoba w sile wieku. Wśród migrantów nieznacznie dominowali mężczyźni. Choć ich przewaga nie była duża, to w okresie 1990-2015 zwiększyła się o 1 p.p. W 2015 roku kobiety stanowiły 48\% migrantów. Mediana wieku migrantów cechowała się wzrostem, co może wskazywać, że proces starzenia się społeczeństw dotyczył również migrantów. W 2015 roku mediana wieku wynosiła 39 lat, co oznacza, że połowa migrantów miała 39 lat lub mniej (ONZ, 2015b, s. 2).

\section{Zmiany w strukturze geograficznej imigracji}

Nie notowano dużych zmian w strukturze geograficznej napływu imigrantów ze względu na poziom rozwoju krajów. Tradycyjnie największym zainteresowaniem cieszyły się państwa wysoko rozwinięte, które w 2015 roku gościły 58\% migrantów (o blisko 4 p.p. więcej niż ćwierć wieku wcześniej - por. rys. 2), natomiast udział krajów rozwijających się i najsłabiej rozwiniętych wśród krajów przyjmujących migrantów zmniejszył się. Spadek ten był mniejszy w przypadku pierwszej grupy krajów o ok. 1 p.p. i aż o 1/3 w grupie drugiej. W 2015 roku nieco ponad 1/3 imigrantów 
przebywała w krajach rozwijających się, a tylko co dwudziesty imigrant w kraju najsłabiej rozwiniętym.

Rysunek 2. Struktura geograficzna napływu imigrantów w latach 1990 i 2015 (\%)

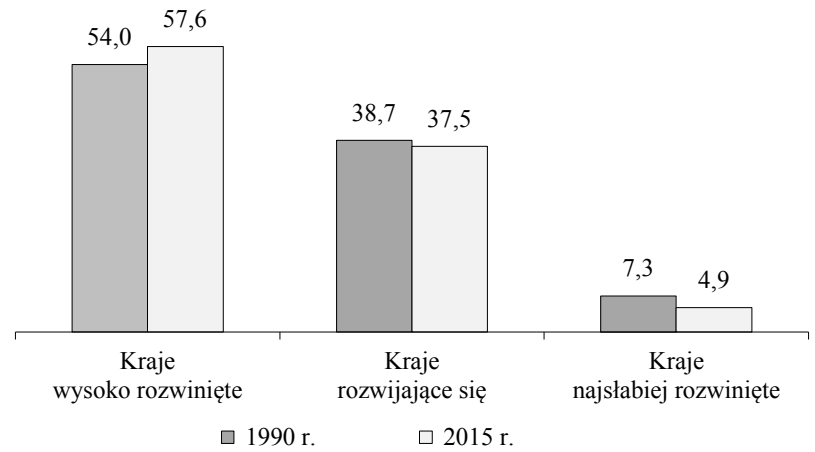

Źródło: opracowanie własne na podstawie ONZ (2015a).

Jeśli chodzi o wybór regionów świata w migracjach międzynarodowych, także i tutaj zaszły zmiany, choć były one niewielkie. Blisko $2 / 3$ migrantów za kraj imigracji wybrało państwa w Europie i Azji (po około 31\% - patrz rys. 3). Notowano niewielki spadek (o ok. 1 p.p.) udziału krajów z tych dwóch kontynentów w wyborze kraju imigracji w stosunku do roku 1990. Na trzecim miejscu znalazł się region Ameryki Północnej, jednak w odróżnieniu od dwóch pierwszych, tutaj odnotowano wzrost z 18 do 22\%, głównie z powodu rosnącego dużego napływu migrantów do USA.

W przypadku kolejnego regionu - Afryki - również odnotowano tendencję spadkową udziału krajów z tej części świata w wyborze kraju migracji. W 2015 roku tylko co dwunasty imigrant osiedlał się w Afryce, choć jeszcze 25 lat wcześniej - co dziesiąty. Najmniej migrantów trafiało do Ameryki Południowej i Środkowej oraz do Australii i Oceanii.

Krajem przyjmującym największą liczbę imigrantów tradycyjnie były USA. Stany Zjednoczone dzieli bardzo duży dystans od kolejnych największych krajów goszczących migrantów. W 2015 roku drugie pod tym względem były Niemcy z ponad o połowę mniejszą liczbą imigrantów, mimo iż 25 lat wcześniej były dopiero szóste (por. tab. 2). Ten znaczący wzrost w ostatnim okresie można głównie 
tłumaczyć dużym napływem uchodźców z Afryki Północnej dotkniętej konfliktem zbrojnym.

Rysunek 3. Struktura geograficzna napływu imigrantów według regionów świata w latach 1990 i 2015 (\%)

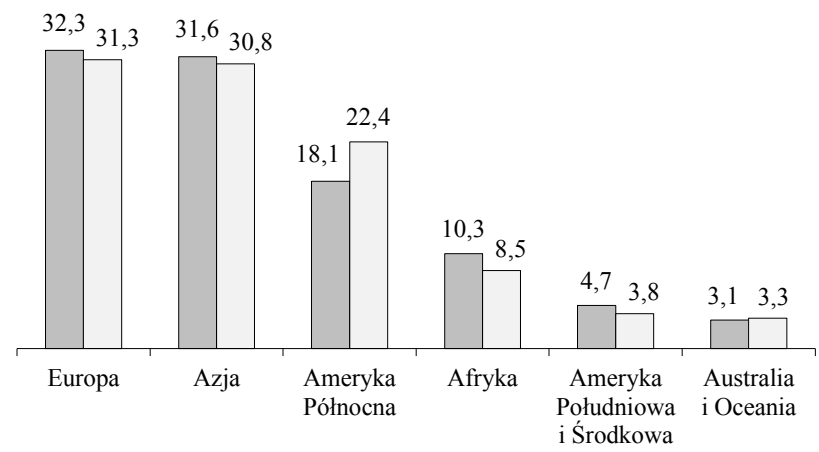

$\square 1990 \mathrm{r} . \quad \square 2015 \mathrm{r}$.

Źródło: opracowanie własne na podstawie ONZ (2015a).

Tabela 2. Kraje posiadające największą liczbę imigrantów w latach 1990 i 2015 (w tys.)

\begin{tabular}{|lr|lr|}
\hline \multicolumn{1}{|c|}{1990} & \multicolumn{2}{c|}{2015} \\
\hline 1. USA & 23251 & 1. USA & 46627 \\
\hline 2. Rosja & 11525 & 2. Niemcy & 12006 \\
\hline 3. Indie & 7493 & 3. Rosja & 11643 \\
\hline 4. Ukraina & 6893 & 4. Arabia Saudyjska & 10186 \\
\hline 5. Pakistan & 6208 & 5. Wielka Brytania & 8543 \\
\hline 6. Niemcy & 5936 & 6. Zjednoczone Emiraty Arabskie & 8095 \\
\hline 7. Francja & 5897 & 7. Kanada & 7836 \\
\hline 8. Arabia Saudyjska & 4998 & 8. Francja & 784 \\
\hline 9. Kanada & 4333 & 9. Australia & 6764 \\
\hline 10. Iran & 4292 & 10. Hiszpania & 653 \\
\hline 29. Polska & 1128 & 60. Polska & 619 \\
\hline
\end{tabular}

Źródło: opracowanie własne na podstawie ONZ (2015a).

Trzecie miejsce zajęła Rosja, w której mieszka wielu obywateli z krajów byłych republik radzieckich. Z kolei czwarta i szósta lokata przypadła krajom naftowym 
- Arabii Saudyjskiej i Zjednoczonym Emiratom Arabskim, przyciągającym znaczne zasoby siły roboczej. W tych ostatnich udział imigrantów w populacji w 2015 roku wynosił aż 88\% (por. tab. 3), jedynie w Katarze był większy - wynosił 97\%. $\mathrm{Na}$ piątym miejscu uplasowała się wielka Brytania, a następnie Kanada, Francja, Australia i Hiszpania. Jeśli natomiast chodzi o Polskę, to w zestawieniu krajów przyjmujących imigrantów znajdowała się dopiero na 60. miejscu.

Tabela 3. Kraje z największym odsetkiem imigrantów wśród ludności w 2013 roku (\%)

\begin{tabular}{|l|c|}
\hline \multicolumn{1}{|c|}{ Kraj } & $\begin{array}{c}\text { Udział imigrantów } \\
\text { w populacji }\end{array}$ \\
\hline Katar & 90,8 \\
\hline Zjednoczone Emiraty Arabskie & 88,5 \\
\hline Samoa & 75,7 \\
\hline Wyspa Sint Maarten (część holenderska) & 73,8 \\
\hline Kuwejt & 72,1 \\
\hline Monako & 64,7 \\
\hline Wyspy Dziewicze & 60,4 \\
\hline Andora & 59,4 \\
\hline Makau & 58,7 \\
\hline Kajmany & 57,7 \\
\hline
\end{tabular}

Źródło: opracowanie własne na podstawie Grupa Banku Światowego (2016).

Biorąc pod uwagę odsetek imigrantów wśród ludności krajów imigracji, wysoki był on zwłaszcza we wspomnianych już wcześniej krajach naftowych oraz w Kuwejcie, ale również w krajach wyspiarskich, np. na Samoa i wyspie Sint Maarten (po ok. 3/4), czy w Europie w Monako i Andorze (blisko 60\%). W pierwszej dziesiątce zestawienia ponad połowę mieszkańców krajów stanowili imigranci.

\section{Zmiany w strukturze geograficznej emigracji}

Nieco inne zmiany zaszły w przeciwnym kierunku przepływu migrantów emigracji. Emigrowali głównie obywatele krajów rozwijających się. W 2015 roku najliczniejszą grupę emigrantów na świecie stanowili Hindusi (15,6 mln osób, ponad dwa razy więcej niż w roku 1990 - por. tab. 4). Na drugim miejscu znaleźli się Meksykanie, w przypadku których wzrost w tym okresie był jeszcze szybszy, bo niemal trzykrotny. Trzecia lokata przypadła Rosjanom, którzy jako jedyni w czołówce 
zestawienia nieco ograniczyli liczbę emigrantów. Duży wzrost emigrantów nastąpił ponadto jeszcze w Chinach, Pakistanie i Bangladeszu. Natomiast wśród krajów rozwiniętych największą liczbę emigrantów zanotowano w Wielkiej Brytanii (4,9 mln osób, 10. pozycja w zestawieniu). Zmiany w tym zakresie nastąpiły również w Polsce. O ile w 1990 roku 1,5 mln obywateli przebywało poza ojczyzną, o tyle ćwierć wieku później było ich już trzy razy więcej. Tym samym nasz kraj wspiął się na 12. pozycję omawianego zestawienia.

Tabela 4. Kraje posiadające największą skumulowaną liczbę emigrantów w latach 1990 i 2015 (w tys.)

\begin{tabular}{|lc|lr|}
\hline \multicolumn{1}{|c|}{1990} & & 2015 \\
\hline 1. Rosja & 12696 & 1. Indie & 15576 \\
\hline 2. Afganistan & 6722 & 2. Meksyk & 12339 \\
\hline 3. Indie & 6717 & 3. Rosja & 10577 \\
\hline 4. Ukraina & 5549 & 4. Chiny & 9546 \\
\hline 5. Bangladesz & 5449 & 5. Bangladesz & 7205 \\
\hline 6. Meksyk & 4393 & 6. Pakistan & 5935 \\
\hline 7. Chiny & 4227 & 7. Ukraina & 5826 \\
\hline 8. Włochy & 3410 & 8. Filipiny & 5316 \\
\hline 9. Pakistan & 3336 & 9. Syria & 5012 \\
\hline 10. Niemcy & 3275 & 10. Wielka Brytania & 4917 \\
\hline 25. Polska & 1532 & 12. Polska & 4450 \\
\hline
\end{tabular}

Źródło: zestawienie własne na podstawie danych ONZ.

Jeśli chodzi o udział emigrantów w populacji danego kraju, to sytuacja przedstawiała się nieco inaczej. W pierwszej dziesiątce dominowały relatywnie niewielkie i głównie wyspiarskie kraje. W zestawieniu z 2013 roku na pierwszym miejscu z bardzo wysokim wynikiem ( $141 \%$ - por. tab. 5) znalazło się Monako. Oznacza to, że więcej Monakijczyków wyjechało i zamieszkało poza granicami kraju niż w nim pozostało. Monako cechuje się ponadto wysokim odsetkiem imigrantów w społeczeństwie (por. tab. 3). Na kolejnych miejscach zestawienia znalazły się Dominika oraz Zachodni Brzeg i Gaza, których wielkość populacji kraju była zbliżona do liczby emigrantów. Dalej uplasowały się natomiast państwa, w których emigranci stanowili ponad połowę populacji krajów - Antigua i Barbuda, Gujana, Samoa, wyspa Sint Maarten, St. Vincent i Grenadyny, Grenada oraz Tonga. 
Tabela 5. Kraje z największym odsetkiem emigrantów wśród ludności w 2013 roku (\%)

\begin{tabular}{|l|c|}
\hline \multicolumn{1}{|c|}{ Kraj } & $\begin{array}{c}\text { Udział emigrantów } \\
\text { w populacji }\end{array}$ \\
\hline Monako & 141,2 \\
\hline Dominika & 106,6 \\
\hline Zachodni Brzeg i Gaza & 96,4 \\
\hline Antigua i Barbuda & 63,2 \\
\hline Gujana & 60,8 \\
\hline Samoa & 60,2 \\
\hline Wyspa Sint Maarten (część holenderska) & 59,6 \\
\hline St. Vincent i Grenadyny & 55,4 \\
\hline Grenada & 54,7 \\
\hline Tonga & 53,6 \\
\hline
\end{tabular}

Źródło: Grupa Banku Światowego (2016).

Największy korytarz migracyjny w 2013 roku znajdował w Ameryce Północnej. Aż 13 milionów osób wyemigrowało z Meksyku do Stanów Zjednoczonych (por. tab. 6) - to niemal cztery razy więcej niż w kolejnym co do wielkości korytarzu migracyjnym z Rosji do Ukrainy. W przeciwnym kierunku natężenie ruchu było nieznacznie niższe, co wynikało z konfliktu rosyjsko-ukraińskiego i prowadzonych tam działań zbrojnych. Bardzo duża skala migracji występowała też z Bangladeszu do Indii, z Chin do USA oraz w obu kierunkach pomiędzy Kazachstanem i Rosją. Ponadto ponad 4 miliony Afgańczyków wyemigrowało do Pakistanu i Iranu.

Tabela 6. Największe korytarze migracyjne w 2013 roku

\begin{tabular}{|l|c|}
\hline \multicolumn{1}{|c|}{ Kierunek migracji } & $\begin{array}{c}\text { Liczba migrantów } \\
\text { w milionach }\end{array}$ \\
\hline Meksyk-USA & 13,0 \\
\hline Rosja-Ukraina & 3,5 \\
\hline Bangladesz-Indie & 3,2 \\
\hline Ukraina-Rosja & 2,9 \\
\hline Kazachstan-Rosja & 2,5 \\
\hline Chiny-USA & 2,4 \\
\hline Rosja-Kazachstan & 2,4 \\
\hline Afganistan-Pakistan & 2,3 \\
\hline Afganistan-Iran & 2,3 \\
\hline Hongkong-Chiny & 2,3 \\
\hline
\end{tabular}




\section{Przekazy migrantów jako efekt migracji międzynarodowych}

Wraz ze wzrostem skali migracji międzynarodowych wzrosły również światowe przekazy migrantów. Wysoki wzrost przekazów notowano zwłaszcza w połowie pierwszej dekady XXI wieku (por. rys. 4). W 2016 roku wyniosły one aż 585 mld USD i były ponad 9 razy większe niż ćwierć wieku wcześniej. W ostatnich dwóch latach notowano nieznaczny spadek przekazów.

Rysunek 4. Przekazy migrantów w okresie 1970-2016 (mld USD)

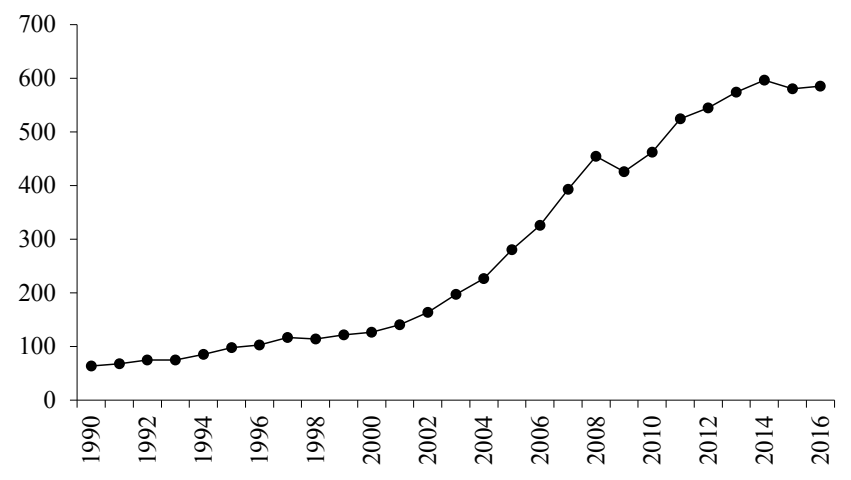

Źródło: opracowanie własne na podstawie danych Banku Światowego, którego kalkulacje bazują na danych z bilansów płatniczych krajów z Międzynarodowego Funduszu Walutowego (Grupa Banku Światowego, 2017).

Najwięcej przekazów migrantów trafiało do dwóch krajów azjatyckich - Indii i Chin. W 2014 roku było to odpowiednio 72 i 64 mld USD (por. tab. 7). O ponad połowę mniej przekazano na Filipiny i do Meksyku. Piąta pod względem wielkości przekazów migrantów była Francja, a dalej Nigeria, Egipt i Pakistan. Na dziewiątym miejscu znalazły się natomiast Niemcy, a na osiemnastym Polska.

Jednak to nie w gospodarkach państw, gdzie przekazy migrantów były największe, grały one największą rolę. Ich odsetek w produkcie krajowym brutto był tam relatywnie niewielki (np. w Polsce 1,4\% PKB - por. tab. 7). Natomiast w krajach niewielkich i rozwijających się, czy też najsłabiej rozwiniętych, stanowiły one bardzo ważny czynnik tworzenia PKB. W 2014 roku w Tadżykistanie międzynarodowe przekazy migrantów stanowiły niemal $42 \%$ PKB, w Kirgistanie i Nepalu około 
$30 \%$, a w Tonga i Mołdawii ponad 1/4 PKB. W państwach tych dochód narodowy był w bardzo silnym stopniu uzależniony od skali transferów migrantów.

Tabela 7. Kraje, które otrzymały największe przekazy imigrantów w 2014 roku

\begin{tabular}{|l|c|l|c|}
\hline \multicolumn{1}{|c|}{ Kraj } & Mld USD & \multicolumn{1}{|c|}{ Kraj } & $\%$ PKB \\
\hline 1. Indie & 72,2 & 1. Tadżykistan & 41,7 \\
\hline 2. Chiny & 63,9 & 2. Kirgistan & 30,3 \\
\hline 3. Filipiny & 29,7 & 3. Nepal & 29,2 \\
\hline 4. Meksyk & 25,7 & 4. Tonga & 27,9 \\
\hline 5. Francja & 24,6 & 5. Mołdawia & 26,2 \\
\hline 6. Nigeria & 20,8 & 6. Liberia & 24,6 \\
\hline 7. Egipt & 20,4 & 7. Bermudy & 23,1 \\
\hline 8. Pakistan & 20,1 & 8. Haiti & 22,7 \\
\hline 9. Niemcy & 17,5 & 9. Komory & 20,0 \\
\hline 10. Bangladesz & 15,8 & 10. Gambia & 1,4 \\
\hline 18. Polska & 7,2 & 100. Polska & \\
\hline
\end{tabular}

Źródło: Grupa Banku Światowego (2016), s. 29, 30.

Tabela 8. Główne kierunki migracji (2013 r.) i przekazów imigrantów (prognoza dla 2015 r.)

\begin{tabular}{|l|c|c|c|c|}
\hline \multirow{2}{*}{ Kierunek przepływu } & \multicolumn{2}{|c|}{ Migracje ludzi } & \multicolumn{2}{c|}{ Przekazy imigrantów } \\
\cline { 2 - 5 } & $\mathrm{mln}$ & $\begin{array}{c}\text { \% migrantów } \\
\text { na świecie }\end{array}$ & mld USD & $\begin{array}{c}\text { \% globalnych } \\
\text { przekazów }\end{array}$ \\
\hline Południe-Południe & 93,1 & 38 & 206,7 & 34 \\
\hline Południe-Północ & 84,3 & 34 & 27,9 & 5 \\
\hline Północ-Północ & 55,7 & 23 & 143,0 & 24 \\
\hline Północ-Południe & 14,2 & 6 & 223,8 & 37 \\
\hline
\end{tabular}

Źródło: opracowanie własne na podstawie Grupa Banku Światowego (2016), s. 28.

Jeśli porównać kierunki międzynarodowego przepływu ludzi z kierunkami przekazów migrantów, to można dostrzec istotne różnice w tym zakresie. 57\% migrantów na świecie za cel migracji wybrało kraje rozwinięte (bogate kraje Północy), podczas gdy przekazy migrantów kierowane były przede wszystkim do ubogich krajów Południa ( $71 \%$ - por. tab. 8). Ta tendencja nie dziwi, gdyż częstym motywem międzynarodowych migracji ludzi są względy ekonomiczne, stąd główny kierunek migracji to państwa rozwinięte. $Z$ kolei strumień przekazów migrantów zwrócony 
jest w kierunku państw, z których migranci pochodzą, celem chociażby wsparcia rodzin. Podkreślenia wymaga jednak fakt, że w 2013 roku migracja pomiędzy krajami rozwijającymi się przewyższyła tę z krajów Południa do krajów Północy, co świadczy o wzroście znaczenia migracji wewnątrzregionalnych.

\section{Podsumowanie}

Z przeprowadzonej analizy wynika, że w okresie 1990-2015 rola migracji międzynarodowych w gospodarce światowej zwiększyła się, wzrosła bowiem zarówno skala migracji, jak i udział migrantów w populacji światowej. Zaszły nieznaczne przeobrażenia w strukturze geograficznej migracji. Dominujący udział krajów rozwiniętych w wyborze kierunków migracji jeszcze bardziej się zwiększył, jednak największe natężenie migracji nie występowało, jak wcześniej z biedniejszych krajów Południa do bogatej Północy, ale pomiędzy krajami rozwijającymi się. Tradycyjnie krajem przyjmującym najwięcej imigrantów były Stany Zjednoczone, przy czym rola USA w tym zakresie jeszcze bardziej się wzmocniła. Inny charakter miały zmiany, które nastąpiły po stronie emigracji. Najwięcej osób wyemigrowało z Indii, Meksyku, Rosji i Chin. Najbardziej odczuwalny odpływ ludzi za granicę był w gospodarkach niewielkich, gdzie liczba emigrantów przekraczała nawet połowę populacji. Wzrostowi migracji międzynarodowych towarzyszył wzrost przekazów migracyjnych skierowanych głównie do uboższych państw Południa. W wielu małych, rozwijających się krajach stanowiły one istotny składnik PKB.

\section{Literatura}

Grupa Banku Światowego (2017). Migration and Remittances Data. Pobrano z: http://www. worldbank.org/en/topic/migrationremittancesdiasporaissues/brief/migration-remittances-data (marzec 2017).

Grupa Banku Światowego (2016). Migration and Remittance Factbook 2016. Pobrano z: http://siteresources.worldbank.org/INTPROSPECTS/Resources/334934-119980 7908806/4549025-1450455807487/Factbookpart1.pdf (marzec 2017).

ONZ (2015a). International Migrant Stock 2015. Pobrano z: http://www.un.org/en/develop ment/desa/population/migration/data/estimates2/estimates15.shtml. 
ONZ (2015b). International Migration Trends Wallchart. Trends in International Migrant Stock: The 2015 Revision. Pobrano z: http://www.un.org/en/development/desa/popula tion/migration/publications/wallchart/docs/MigrationWallChart2015.pdf.

ONZ (2015c). Trends in International Migration 2015. Pobrano z: http://www.un.org/en/ development/desa/population/migration/publications/populationfacts/docs/Migra tionPopFacts20154.pdf.

ONZ (2016). Baza danych. Pobrano z: https://esa.un.org/unpd/wpp/DataQuery (marzec 2017).

\title{
TRENDS IN INTERNATIONAL MIGRATION
}

\begin{abstract}
The aim of the study is to present trends in the area of contemporary international migrations in the last quarter century. The study consists of four parts. The first analyzes the changes in the volume and dynamics of migration, the second examines changes in the direction of immigration, the third emigration, and the fourth discusses remittances. The results show that the scale of migration and its importance in the world economy have increased. There have been minor changes in migration directions. The dominant share of developed countries in the choice of host countries has increased. The country with the largest number of immigrants is still the US. The country from which most people emigrated became India, followed by Mexico and Russia. The greatest intensity of migration occurred between developing countries. There has been an increase in remittances, mainly to the South.
\end{abstract}

Keywords: international migration, remittances, emigration, immigration

JEL codes: F22, F24 